\title{
Wildebeest (Connochaetes taurinus) Population Densities and Distribution in Dry and Wet Season in the Kilimanjaro Landscape
}

\author{
Noah Sitati ${ }^{*}$, Kenana Lekishon ${ }^{2}$, Samuel Bakari ${ }^{3}$, Fiesta Warinwa ${ }^{1}$, \\ Stephen Ndambuki Mwiư ${ }^{2}$, Nathan Gichohi' ${ }^{1}$, Elphas Bitok ${ }^{2}$, Machoke Mwita ${ }^{3}$, \\ Hamza K. Ija ${ }^{3}$, Joseph Mukeka² \\ ${ }^{1}$ African Wildlife Foundation, Namanga, Kenya \\ ${ }^{2}$ Kenya Wildlife Service, Nairobi, Kenya \\ ${ }^{3}$ Tanzania Wildlife Research Institute, Arusha, Tanzania \\ Email: "
}

Received 27 June 2014; revised 2 August 2014; accepted 18 August 2014

Copyright (C) 2014 by authors and Scientific Research Publishing Inc.

This work is licensed under the Creative Commons Attribution International License (CC BY).

http://creativecommons.org/licenses/by/4.0/

(c) (i) Open Access

\begin{abstract}
The conservation of migratory wildlife species in the savannah habitat can be a challenge because of frequent and prolonged drought and their requirements for a large area. We investigated the performance of the wildebeest (Connochaetes taurinus) population in the $25,624 \mathrm{~km}^{2}$ Kilimanjaro landscape of Kenya and Tanzania, which comprises Amboseli-West Kilimanjaro-Magadi-Natron after 2009 drought. We used total aerial counts to determine the spatial distribution and numbers of wildebeests during wet and dry season in 2010 and 2013. Global Positioning System and digital voice recorders were used to count wildebeests along established transects within blocks. There was an increase in the wildebeest population by $103 \%$ during the wet season and $14 \%$ during the dry season between 2010 and 2013. The seasonal variation in density occurred between the four counting blocks with Natron and Magadi areas recording the highest densities. Generally, the increase in population could be attributed to the recovery of the population after the 2009 drought. The current cross border collaboration between Kenya and Tanzania in aerial surveys is an important step in the conservation of this migratory species in the landscape. This study demonstrates that detailed knowledge of density and spatial distribution of migratory species is required to plan effective conservation action.
\end{abstract}

"Corresponding author.

How to cite this paper: Sitati, N., Lekishon, K., Bakari, S., Warinwa, F., Mwiu, S.N., Gichohi, N., Bitok, E., Mwita, M., lja, H.K. and Mukeka, J. (2014) Wildebeest (Connochaetes taurinus) Population Densities and Distribution in Dry and Wet Season in the Kilimanjaro Landscape. Natural Resources, 5, 810-821. http://dx.doi.org/10.4236/nr.2014.513070 


\section{Keywords}

\section{Aerial Count, Density, Kilimanjaro Landscape, Seasons, Wildebeest, Trans-Boundary}

\section{Introduction}

Populations of wildebeest (Connochaetes taurinus) still persist in various parts of the African savanna biome, although both population types have suffered declines in various parts of the species' range. Huge declines in wildebeest population have been reported in the Masai Mara ecosystem by $81 \%$ [1], in Botswana by $90 \%$ [2], in Kruger National Park by 87\% [3] [4] and in Etosha National Park [5]. The declines were attributed to many factors including an anthrax epidemic, elevated predation rates, droughts, veterinary fences, hunting and competition with livestock [1]-[4] [6].

Drought is one of the environmental factors that are highly listed as an explanatory variable for the decline of most wildlife species. Africa's savannah biomes are currently experiencing frequent and prolonged droughts [7]. The impact of drought which is climate-related has been related to nutritional factors dependent on intra-annual rainfall patterns, such as dry season rainfall [8]. For instance, wildebeest numbers are negatively correlated with annual rainfall in the Mara-Serengeti ecosystem [9] [10]. The survival of wildebeests in the changing weather patterns therefore depends on their migratory behavior. While the underlying causes of the migration are not yet fully understood [11], the main factor influencing the migration, however, is thought to be rainfall through its effect on food or salinity [12]-[14] and energy maximization and nutrient availability [15] [16].

The Kilimanjaro landscape covers $25,623 \mathrm{~km}^{2}$ on the border of Kenya and Tanzania. This landscape has one of Africa's most extensive unprotected areas with most areas of the landscape managed for conservation by local communities. These areas are very large, for example, the Amboseli conservancies and group ranches, Natron and Enduimet Wildlife Management Area cover $8824 \mathrm{~km}^{2}, 3013 \mathrm{~km}^{2}$ and $7047 \mathrm{~km}^{2}$ respectively, compared with $392 \mathrm{~km}^{2}$ area of Amboseli National Park. Despite this vast area, only $25.6 \%$ is protected area which cannot sustain the wildebeest population; hence, concerns have been expressed over the ability of the protected area to conserve biodiversity. These include the blockage of migratory corridors that link the adjacent protected areas [17], the increasing conversion of wildebeest range and habitat into cultivation [18] [19] and the unplanned tourism development [20]. The corridors link the landscape to Chyulu and Tsavo National Parks to the east and Kilimanjaro National Park to the south [21].

The Kilimanjaro landscape has been well studied over the past 40 years [22]-[25]. Most of these studies have, however, focused on smaller portions of the linked ecosystems, mainly confined within national administrative boundaries in the two countries. Consequently, the wider picture of the landscape cross-border ecological area in terms of wildlife population monitoring has not been adequately captured. With the increasing knowledge of animal movements within this landscape and observations of fluctuating animal numbers within each country, it has become necessary to have broader landscape surveys.

In this paper, we compare the wildebeest numbers between 2010 and 2013 wet and dry season counts in the trans-boundary Kilimanjaro landscape. We present the abundance and spatial distribution of wildebeest based on total aerial counts surveys.

\section{Study Area}

The Kilimanjaro landscape $\left(1^{\circ} 37^{\prime} \mathrm{S}\right.$ and $3^{\circ} 13^{\prime} \mathrm{S}$ and $35^{\circ} 49^{\prime} \mathrm{E}$ and $\left.38^{\circ} 00^{\prime} \mathrm{E}\right)$, covering about $25,624 \mathrm{~km}^{2}$ comprises a protected and non-protected areas in Kenya and Tanzania [26] covering portions of southern Kenya and northern Tanzania It also comprises two ecologically linked cross-border ecosystems: the Amboseli-West Kilimanjaro ecosystem to the east, and the Magadi-Natron ecosystem to the west (Figure 1). The landscape is roughly divided by a geological complex of basement hills and step-faults that makeup the eastern wall of the KenyaTanzania portion of the East African Rift Valley. It includes the Amboseli National Park and the surrounding group ranches extending to the Chyulu Hills to east and Magadi to the west in Kenya. In Tanzania, it encompasses the West Kilimanjaro area and Mount Meru Forest Reserve to the south and Lake Natronto the west. 


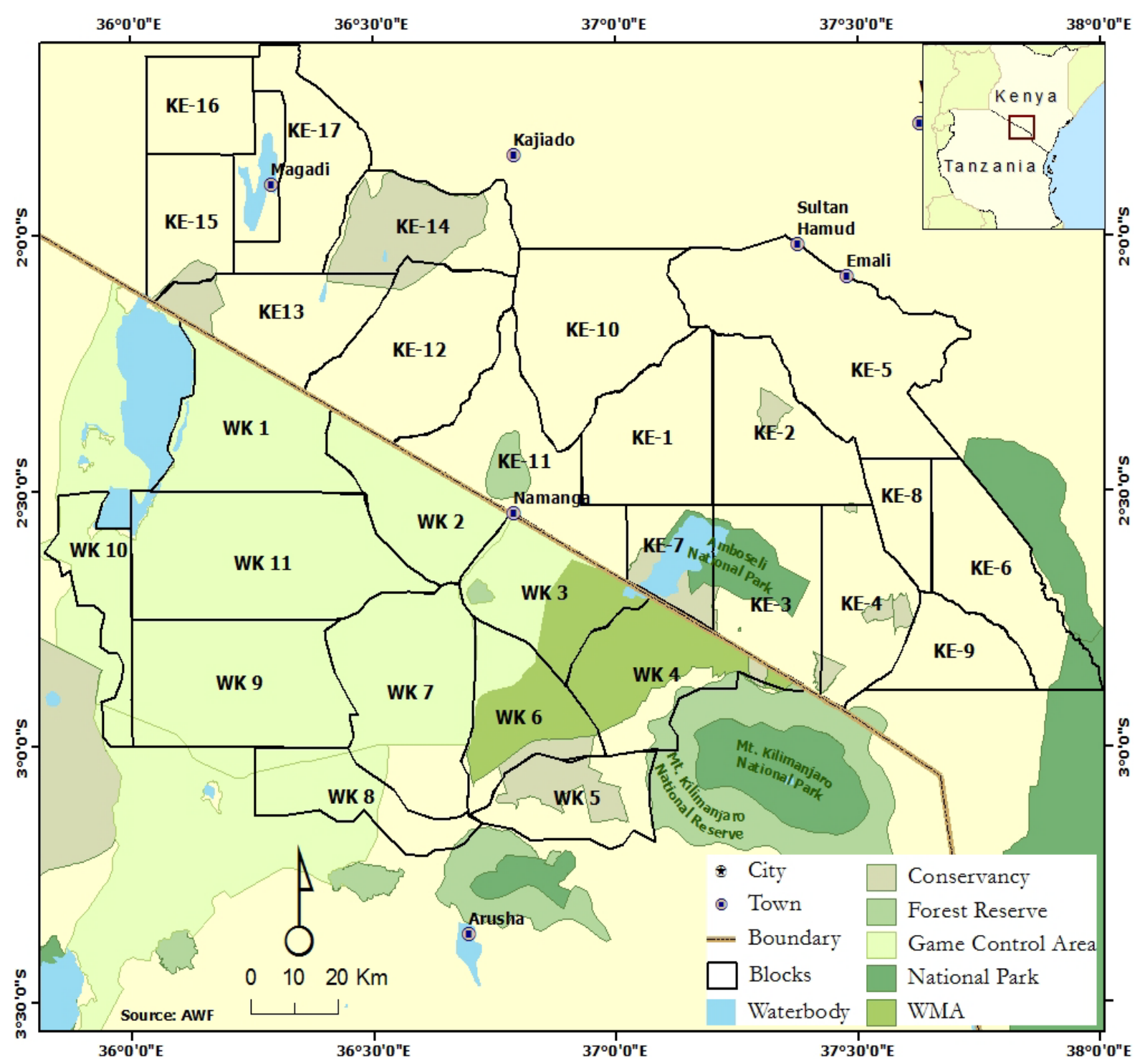

Figure 1. Amboseli-West Kilimanjaro-Magadi-Natron Landscape covers portions of Southern Kenya and Northern Tanzania comprising the Amboseli National Park and Magadiin Kenya and West Kilimanjaro and Natronin Tanzania with survey blocks.

The vegetation in the landscape is dominated by grasslands, bushed and wooded grasslands. The savanna vegetation is dominated by Acacia spp. woodlands and open grasslands [22]. Kilimanjaro has an average rainfall of $500 \mathrm{~mm}$ year mostly falling in between the months of March and May. The dry period is between September and February. However, are as close to Mt Kilimanjaro and the hilly areas in Natron receive substantial rainfall (Sitati et al., in press).

\section{Methodology}

Wildebeest counts were undertaken by a team of trained and experienced biologists in March (wet season) and October (dry season) 2010 and May (wet season) and October (dry season) 2013 using the total count flight technique [27]. The study area was divided into 28 blocks; 17 in Kenya and 11 Tanzania (Figure 2). Each block was systematically surveyed along $1-2 \mathrm{~km}$ width transects oriented either North South or East West directions, depending on visibility and terrain. In the mountainous areas, irregular transects were undertaken (Figure 2). Transects were surveyed at a mean altitude of $383.8 \pm 251$ feet above the ground and a mean speed of $156 \mathrm{Kph}$. 


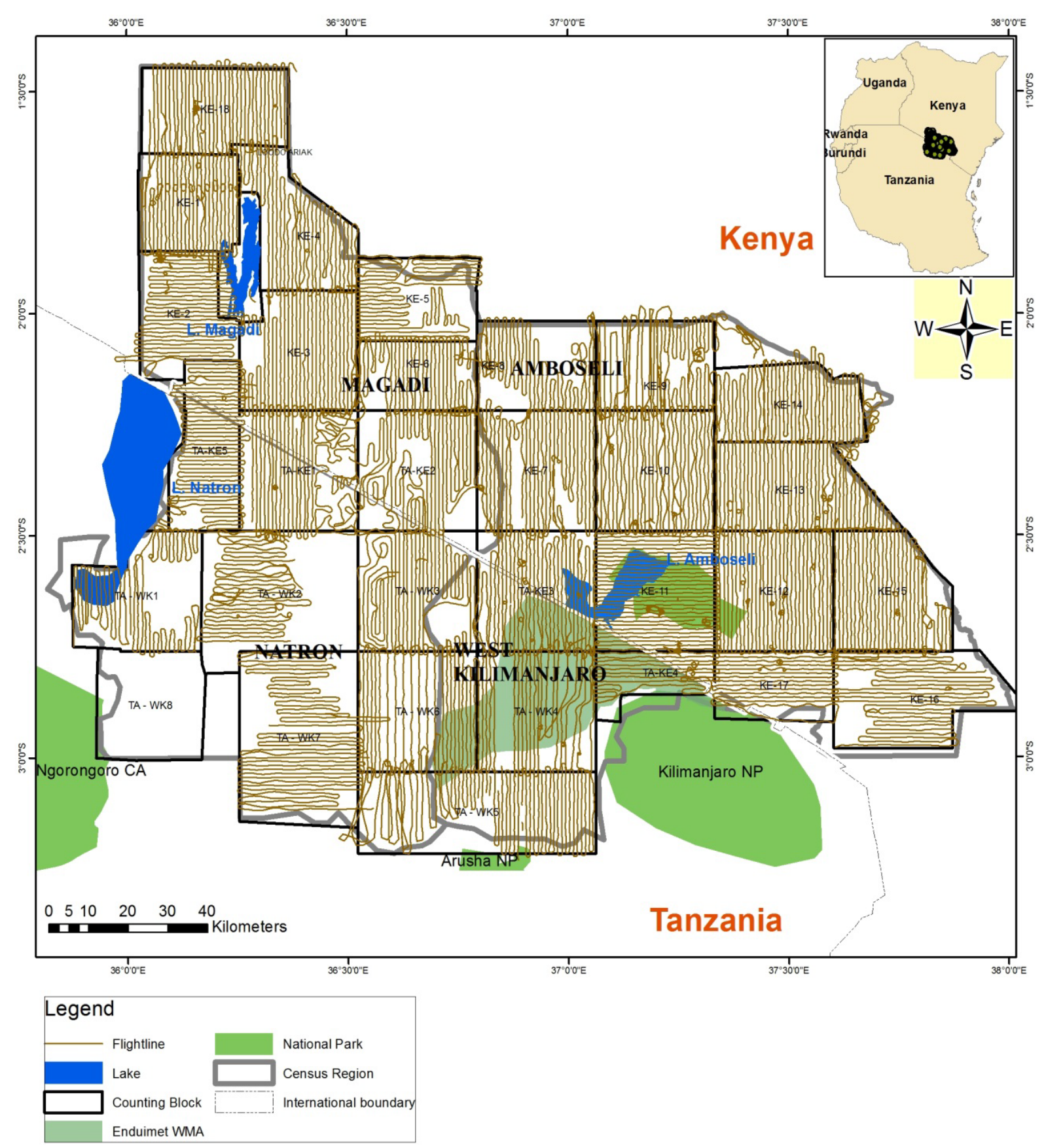

Figure 2. Survey blocks and flight paths used in the study area.

Two experienced and well trained observers [28] occupied the rear seats of a high-wing aircraft and counted animals that appeared between two rods attached to the wing struts. The field of vision between these rods was calibrated by flying repeatedly across ground markers of known spacing [29]. The number of wildebeests falling within the survey strips on either side of the aircraft along each $5 \mathrm{~km}$ transect segment were counted and recorded into tape recorders and on a data sheet.

For each observation a waypoint was marked on a hand held Global Positioning System (GPS). Large herds of wildebeests of more than ten in number were photographed and later tallied to verify the counted individuals. The GPS data was down loaded using DNR-Garmin/Map Source software processed using ArcGIS 9.2 program. Using Statistical Package for Social Sciences [30] version 20.0 (SPSS Inc., Chicago, Illinois, USA), calculations 
made across the count blocks and the entire survey area. GIS based distribution and density maps were generated to depict the spatial extent and distribution of wildebeests.

\section{Results}

\subsection{Wet and Dry Season Counts in 2010}

During the 2010 wet season, 7240 wildebeests were estimated at a density of $0.300 \mathrm{~km}^{2}$. Most of the wildebeest were in the Amboseli, Natron and Magadi areas and were absent in blocks KE-12 (Meto-Longoswa) WK-2 (Longido area) and WK-5 (West Kilimanjaro ranch). In Magadi area, they were mostly confined in block KE-15 (Shompole Group Ranch). In West Kilimanjaro area, wildebeest were in blocks WK-3 and KE-7 (KetendenEnduimet), near the Kenya and Tanzania border, while in Natron area they were in block WK-9. The highest density was recorded in the Amboseli $\left(0.39 / \mathrm{km}^{2}\right)$, followed by Natron $\left(0.30 / \mathrm{km}^{2}\right)$, Magadi $\left(0.29 / \mathrm{km}^{2}\right)$ and West Kilimanjaro with $0.04 / \mathrm{km}^{2}$, respectively (Table 1, Figure 3(a)).

During the 2010 dry season, 7780 wildebeests were derived with a density of $0.314 \mathrm{~km}^{2}$ (Table 1 ). The Amboseli-Magadi area in Kenyan had $61 \%$ of the population while $39 \%$ was in the West Kilimanjaro-Lake Natron in Tanzania. However, among the four survey areas, Natron had the highest $(36 \%)$ wildebeest population followed by Amboseli (32\%), Magadi (29\%) and finally West Kilimanjaro with 3\%, respectively. These populations had densities of $0.40 / \mathrm{km}^{2}, 0.27 / \mathrm{km}^{2}, 0.41 / \mathrm{km}^{2}$ and $0.06 / \mathrm{km}^{2}$, respectively (Table 1 ). In entire survey area, the population were concentrated in south of Lake Natron (WK-10, 11), southwest of lake Magadi-Shombole group ranch (KE-15) and Amboseli NP (KE-3, 7) (Figure 3(b)). There was sparse distribution in west Kilimanjaro and Mbirikani group ranch.

\subsection{Wet and Dry Season Counts and Density in 2013}

During the 2013 wet season survey, 14,728 wildebeests were estimated with a density of $0.575 \mathrm{~km}^{2}$. Most of the wildebeest were in Natron, Amboseli and Magadi and few individuals were recorded in West Kilimanjaro ranch. The highest density was recorded in Natron $\left(1.06 / \mathrm{km}^{2}\right)$ followed by Amboseli $\left(0.423 / \mathrm{km}^{2}\right)$, Magadi $\left(0.376 / \mathrm{km}^{2}\right)$ and West Kilimanjaro had the lowest $\left(0.318 / \mathrm{km}^{2}\right)$ density (Table 1, Figure 4(a)).

However, during the 2013 dry season count, 8862 wildebeests were counted with a density of $0.346 / \mathrm{km}^{2}$. The wildebeests were distributed mainly in Amboseli National Park, south of Natron and Shompole in Magadi. Few individuals were recorded on Amboseli group ranches while no wildebeests were recorded in West Kilimanjaro. Amboseli recorded the highest density $\left(0.621 / \mathrm{km}^{2}\right)$ followed by Magadi $\left(0.262 / \mathrm{km}^{2}\right)$, Natron $\left(0.182 / \mathrm{km}^{2}\right)$ and finally West Kilimanjaro had the lowest density $\left(0.063 / \mathrm{km}^{2}\right)$ (Table 1, Figure 4(b)).

\section{Discussion}

The results of this study demonstrate that there has been an increase in wildebeest numbers since the devastating drought of 2007-2009. Compared with 2010 surveys, [31] [32], the 2013 census shows a general rise in wildebeest population and their abundance but with similar spatial distributions across the landscape. Wildebeests and other ungulates including zebra (Equus burchelli), Grant's gazelle (Gazelle granti) and Thomson's gazelle ( $\mathrm{Ga}$ zelle thomsonii) were greatly affected by the 2009 drought (Western, pers communication). This increase may be

Table 1. Seasonal wildebeest densities distributed by the four survey areas namely, Amboseli and Magadi in Kenya (KE) and West Kilimanjaro and Natron in Tanzania (TZ) during the 2010 and 2013 surveys.

\begin{tabular}{|c|c|c|c|c|}
\hline \multirow{2}{*}{ Survey area } & \multicolumn{4}{|c|}{ Wildebeest densities $\left(\mathrm{km}^{2}\right)$} \\
\hline & Wet season 2010 & Dry season 2010 & Wet season 2013 & Dry season 2013 \\
\hline Amboseli (KE) & 0.391 & 0.271 & 0.423 & 0.621 \\
\hline Magadi (KE) & 0.290 & 0.410 & 0.376 & 0.262 \\
\hline West Kilimanjaro (TZ) & 0.040 & 0.060 & 0.318 & 0.063 \\
\hline Natron (TZ) & 0.302 & 0.403 & 1.061 & 0.182 \\
\hline Average density $\left(\mathrm{km}^{2}\right)$ & 0.300 & 0.314 & 0.575 & 0.346 \\
\hline
\end{tabular}



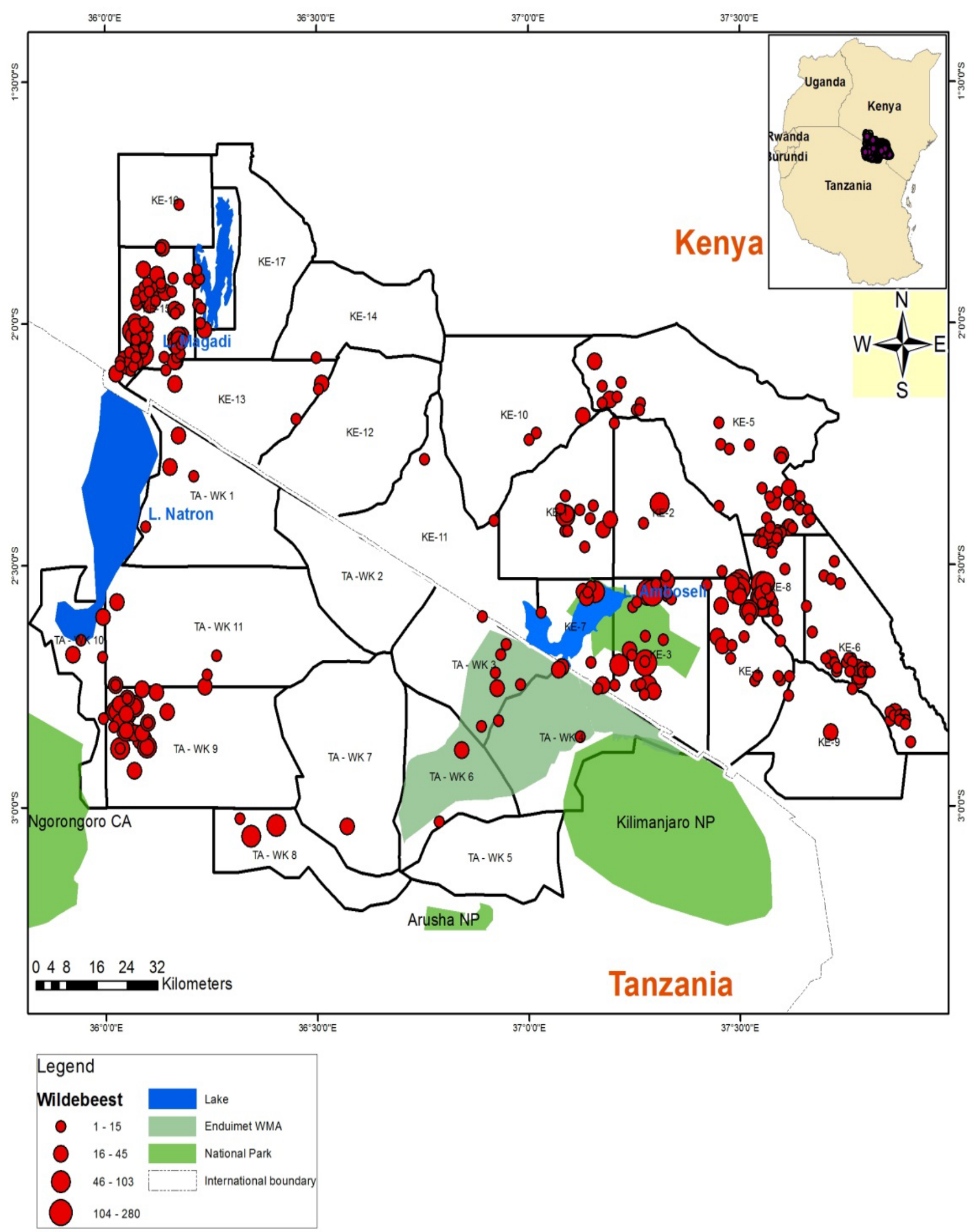

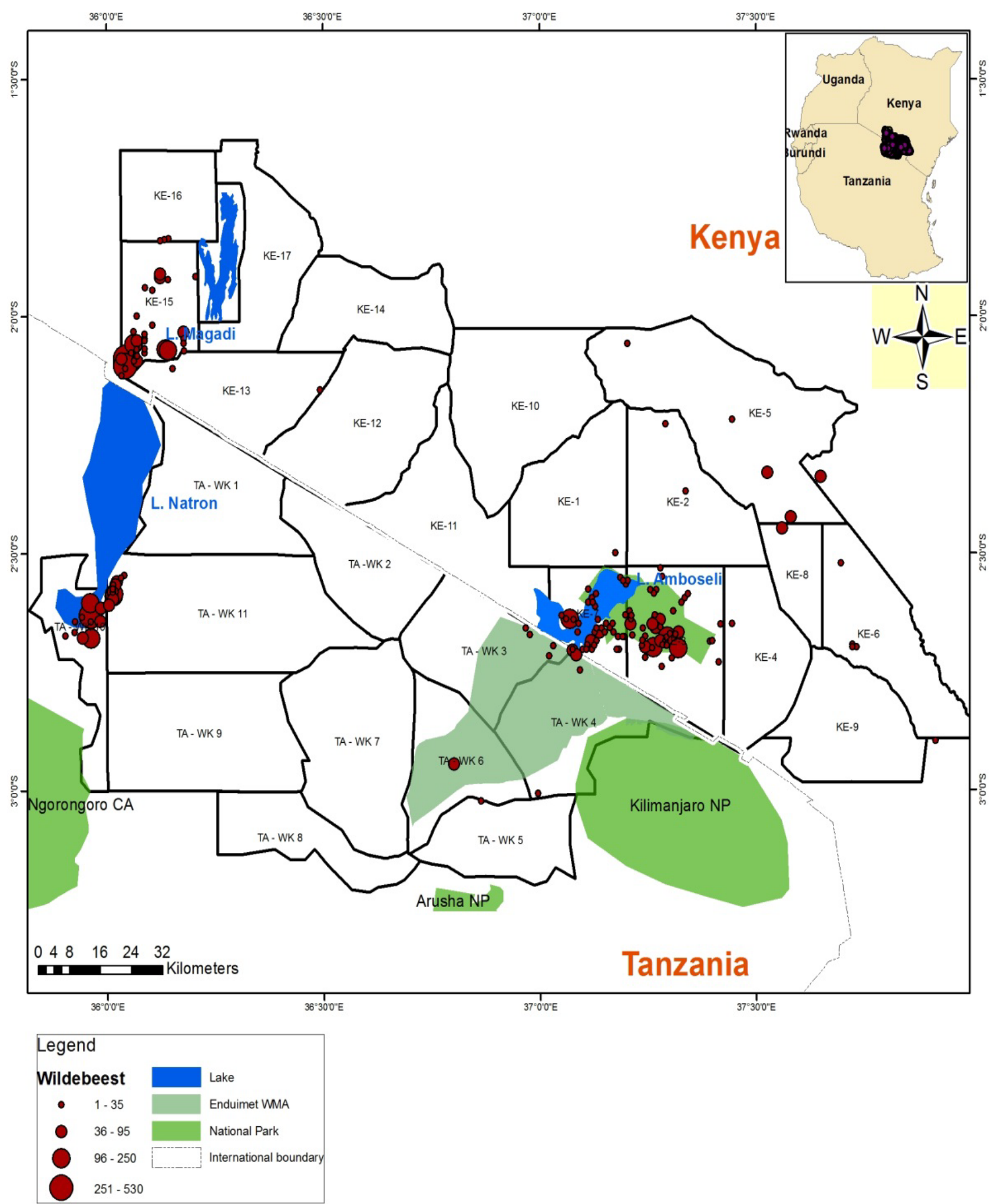

(b)

Figure 3. (a) Distribution of wildebeests during the wet season in 2010; (b) Distribution of wildebeests during the dry season in 2010 . 

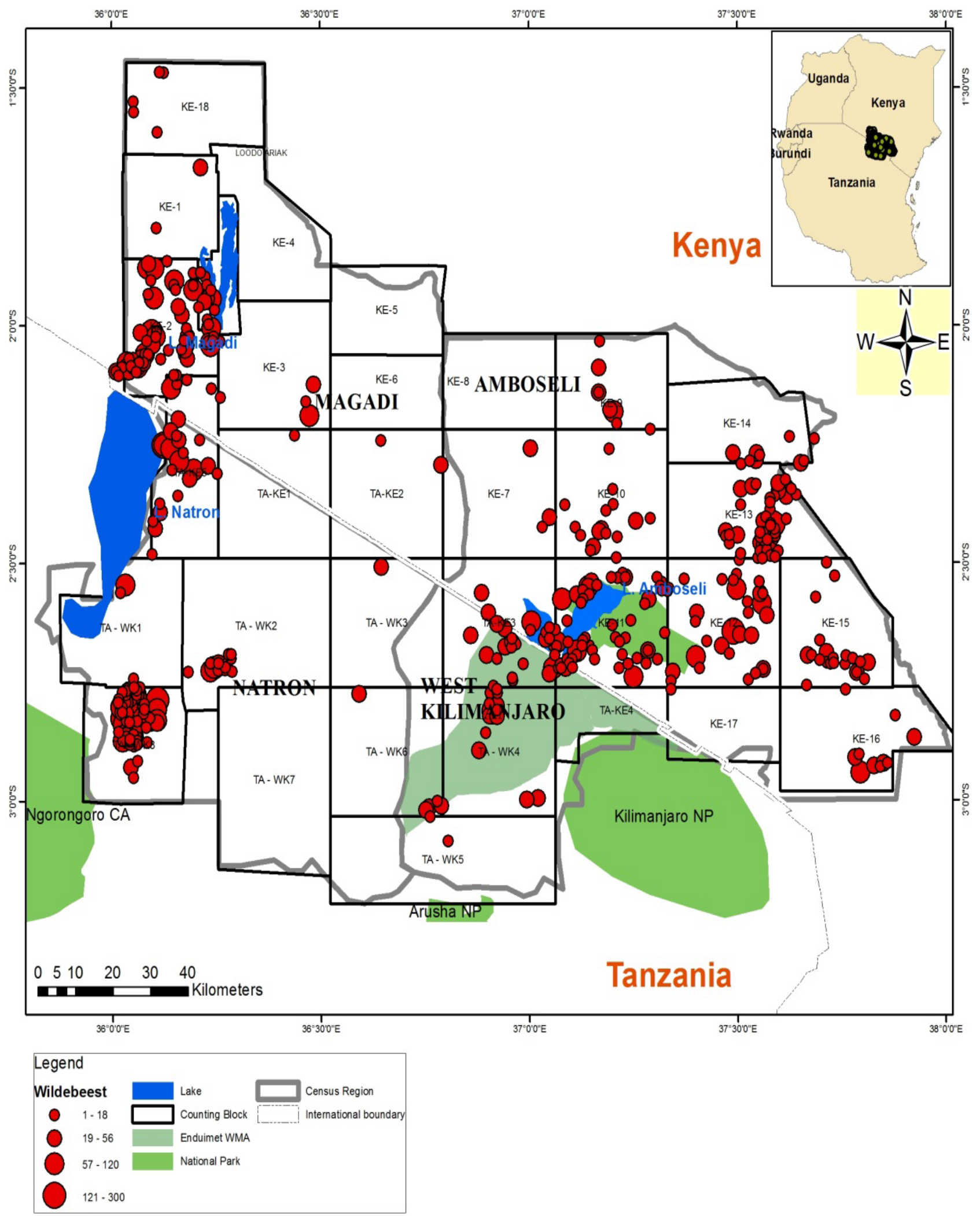

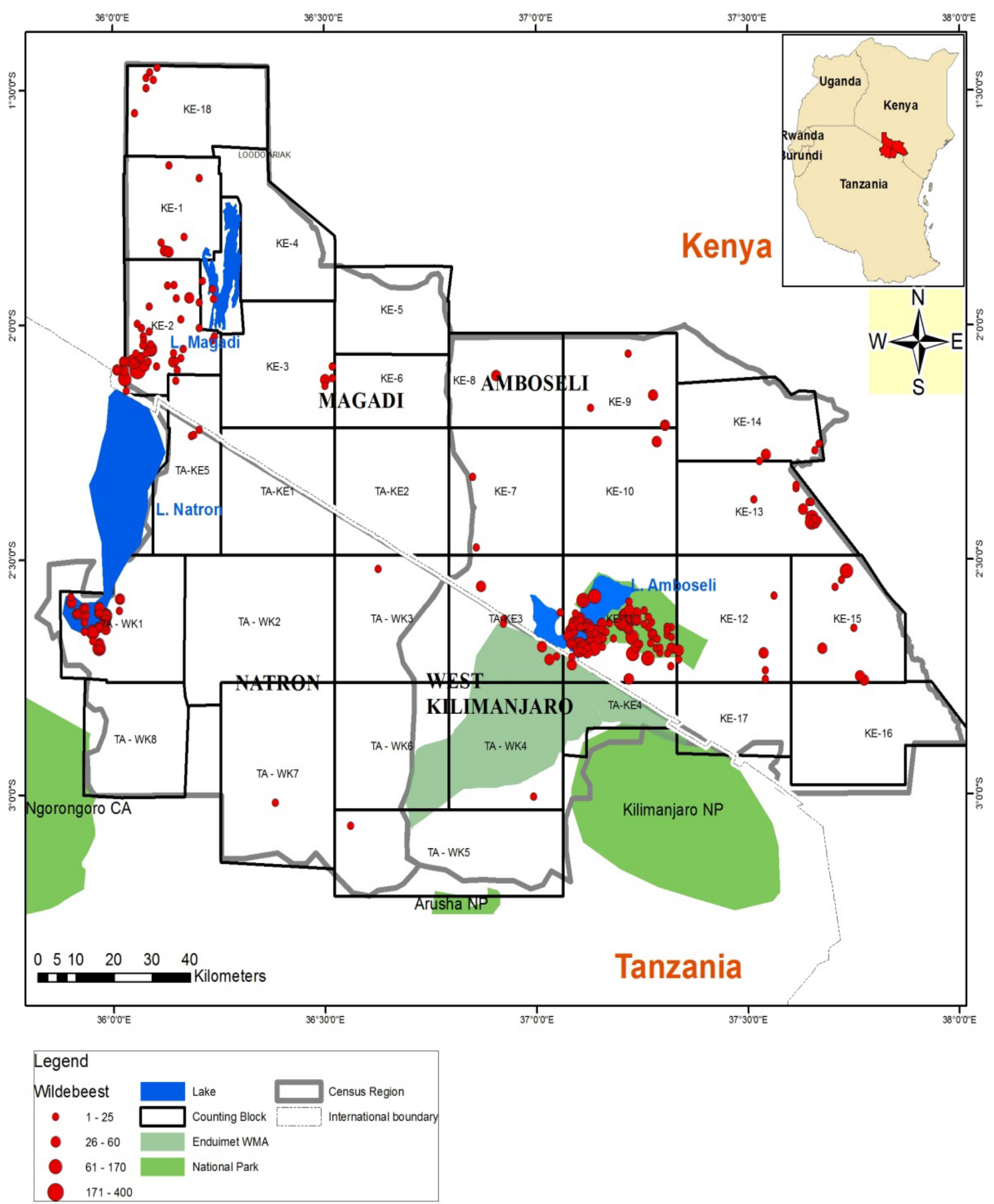

(b)

Figure 4. (a) Distribution of wildebeests during the wet season in 2013; (b) Distribution of wildebeests during the dry season in 2013. 
attributed to favorable climatic conditions where the region experienced for a while after a severe drought and recovery of habitat. Out of 24 large mammals recorded in the landscape, wildebeest was the most abundant wildlife species after zebra (Equus burchelli) during the dry season [33].

According to the surveys, wildebeests are generally widely distributed in the landscape. However, the highest concentrations of all observations are recorded in the Amboseli, probably as a result of the availability of water in the wetlands found in the park and outside [19]. During the wet season, wildebeests are widely distributed outside the park as a result of the availability of alternative sources of water. This underscores the importance of the areas outside the park as wildlife dispersal ranges that should be protected from dangers of fragmentation or subdivision. Efforts, therefore, need to be made to secure areas that have not been converted to alternative uses, such as agriculture.

Natron has recorded the highest density of wildebeests followed by Magadi (Table 1). However, West Kilimanjaro has recorded the lowest density. This shows a discernible seasonal change in their distribution in the landscape, although there may be no direct evidence linking the Kilimanjaro landscape wildebeest population with the Mara-Serengeti population. Recent studies of collared wildebeests in Kenya indicate that the wildebeest wander to most of the landscape including Mara-Serengeti and Ngorongoro [34]. These studies suggest that there are more interactive wildebeest movements within the greater Kilimanjaro landscape, and cross border collaboration and census need to be enhanced. It is also possible that the slight fluctuations could be caused by wildebeests dispersing into un-surveyed areas like Tsavo West.

Apart from droughts and diseases, there are no other serious threats that endanger wildebeests in the landscape. However, environmental degradation caused by commercialized charcoal production in Amboseli and Magadi regions reduces wildebeest range and habitat [17]. Hence, in the absence of the two, the wildebeest population showed an increase of $12 \%$ between 2010 and 2013. This is explained by the fact that the wildebeests migrate during the dry season and congregate during the wet season. However, the variation may also be attributed to low probability of detection during the dry season when there is reduced visual contrast between animals and ground features [1]. Moreover, in the dry season, there is a tendency of herds clustering a lot which makes counting difficult and may result in undercounts [1] [27].

The wildebeest density also varied between the contiguous areas of Amboseli and West Kilimanjaro and similarly between Magadi and Natron. This variation is likely due to the fact that each of these contiguous areas sharing the same population of wildebeest which move freely between them. This again underscores the importance of the landscape as a strategic cross-border wildlife conservation unit that provides wildlife with the required resources throughout the year. Therefore, securing the dispersal area from any form of threat that will endanger its ability to sustain wildlife especially migratory species in the future is imperative.

In conclusion, the surveys have demonstrated the importance of the Kilimanjaro cross-border landscape as a wildebeest conservation and dispersal area. As a migratory species, wildebeests move within and across the various constituent areas of the landscape. Thus, the landscape approach to its future wet and dry season surveys and general conservations are crucial for decision making and understanding the dynamics in the numbers and distribution.

\section{Acknowledgements}

We thank the Royal Netherlands (RNE Activity No. 23856) and USAID SCAPES (Agreement No. EEM-A-0009-00011-00) Project for funding African Wildlife Foundation (AWF) to undertake these surveys. We also wish to thank everybody who has involved in the survey from Kenya and Tanzania. Specifically, we are grateful to the Governments of Kenya and Tanzania for allowing the census to be undertaken, and Mwalunganje Elephant Trust, David Sheldrick Trust, Tsavo Elephant Trust and Mr. Peter Zannetti for providing aircrafts and experienced pilots and observers. Finally, we are very grateful to Oltukai Lodge for hosting the team.

\section{References}

[1] Ottichilo, W.K., de Leeuw, J. and Prins, H.H.T. (2001) Population Trends of Resident Wildebeest [Connochaetes taurinus hecki (Neumann)] and Factors Influencing Them in the Masai Mara Ecosystem, Kenya. Biological Conservation, 97, 271-282. http://dx.doi.org/10.1016/S0006-3207(00)00090-2

[2] Spinage, C.A. (1992) The Decline of the Kalahari Wildebeest. Oryx, 26, 147-150. http://dx.doi.org/10.1017/S0030605300023577 
[3] Whyte, I.J. (1985) The Present Ecological Status of the Blue Wildebeest (Connochaetes taurinus, Burchell, 1823) in the Central District of the Kruger National Park. M.Sc. Thesis, University of Natal, Pietermaritzburg.

[4] Whyte, I.J. and Joubert, S.C.J. (1988) Blue Wildebeest Population Trends in the Kruger National Park and the Effects of Fencing. South African Journal of Wildlife Research, 18, 78-87.

[5] Berry, H.H. (1981) Abnormal Level of Disease and Predation as Limiting Factors for Wildebeest in the Etosha National Park. Madoqua, 12, 242-252.

[6] Starfield, A.M., Smuts, G.L. and Shiell, J.D. (1976) A Simple Wildebeest Population Model and Its Applications. South African Journal of Wildlife Research, 6, 95-98.

[7] Ogutu, J.O. and Owen-Smith, N. (2003) ENSO, Rainfall and Temperature Influences on Extreme Population Declines among African Savanna Ungulates. Ecology Letters, 6, 412-419. http://dx.doi.org/10.1046/j.1461-0248.2003.00447.x

[8] Mduma, S.A.R., Sinclair, A.R.E. and Hilborn, R. (1999) Food Regulates the Serengeti Wildebeest: A 40-Year Record. Journal of Animal Ecology, 68, 1101-1122. http://dx.doi.org/10.1046/j.1365-2656.1999.00352.x

[9] Sitati, N.W. and Wishitemi, B.E.L. (2003) Wildebeest Migration and Tourism Seasonality Pattern and Dynamics in the Mara Ecosystem, Kenya. African Journal of Business and Economics, 2, No. 1.

[10] Ogutu, J., Owen-Smith, N., Piepho, H.P. and Said, M.Y. (2011) Continuing Wildlife Population Declines and Range Contraction in the Mara Region of Kenya during 1977-2009. Journal of Zoology, 285, 99-109. http://dx.doi.org/10.1111/j.1469-7998.2011.00818.x

[11] Sinclair, A.R.E. (1995) Population Limitation of Resident Herbivores. In: Sinclair, A.R.E. and Arcese, P., Eds., Serengeti II: Research, Management and Conservation of an Ecosystem, University of Chicago Press, Chicago, 194-219.

[12] Maddock, L. (1979) The Migration and Grazing Succession. In: Sinclair, A.R.E. and Arcese, P., Eds., University of Chicago Press, Chicago, 104-129.

[13] Wilmshurst, J.F., Fryxell, J.M., Farm, B.P., Sinclair, A.R.E. and Henschel, C.P. (1999) Spatial Distribution of Serengeti Wildebeest in Relation to Resources. Canadian Journal of Zoology, 77, 1223-1232. http://dx.doi.org/10.1139/z99-088

[14] Wolanski, E., Gereta, E., Borner, M. and Mduma, S. (1999) Water, Migration and the Serengeti Ecosystem. American Scientist, 87, 526-523. http://dx.doi.org/10.1511/1999.42.838

[15] Fryxell, J.M. (1995) Aggregation and Migration by Grazing Ungulatesin Relation to Resources and Predators. In: Sinclair, A.R.E. and Arcese, P., Eds., Serengeti II, University of Chicago Press, Chicago, 257-273.

[16] Murray, M.G. (1995) Specific Nutrient Requirements and Migration of Wildebeest. In: Sinclair, A.R.E. and Arcese, P., Eds., Serengeti II, University of Chicago Press, Chicago, 231-256.

[17] Okello, M.M. (2005) Land Use Changes and Human-Wildlife Conflicts in the Amboseli Area, Kenya. Human Dimensions of Wildlife, 10, 19-28. http://dx.doi.org/10.1080/10871200590904851

[18] Serneels, S. and Lambin, E. (2001) Impact of Land-Use Change on the Wildebeest Migration in the Northern Part of the Serengeti-Mara Ecosystem. Journal of Biogeography, 28, 391-407. http://dx.doi.org/10.1046/j.1365-2699.2001.00557.x

[19] Okello, M.M. and Kiringe, J.W. (2004) Threats to Biodiversity and the Implications in Protected and Adjacent Dispersal Areas of Kenya. Journal of Sustainable Tourism, 12, 55-69. http://dx.doi.org/10.1080/09669580408667224

[20] Okello, M.M., Wishitemi, B.E. and Lagat, B. (2005) Tourism Potential and Achievement of Protected Areas in Kenya: Criteria and Prioritization. Tourism Analysis, 10, 151-164. http://dx.doi.org/10.3727/108354205776259286

[21] Croze, H., Sayialel, S. and Sitonic, D. (2006) What's on in the Ecosystem: Amboseli as a Biosphere Reserve. A Compendium of Conservation and Management Activities in the Amboseli Ecosystem. ATE/AERP, UNESCO/MAB, Nairobi, $28 \mathrm{p}$.

[22] Western, D. (1973) The Structure, Dynamics, and Changes of the Amboseli Ecosystem. Ph.D. Thesis, University of Nairobi, Nairobi.

[23] Western, D. and Van Praet, C. (1973) Cyclical Changes in the Habitat and Climate of an East African Ecosystem. Nature, 241, 104-106. http://dx.doi.org/10.1038/241104a0

[24] TWCM (1998) Aerial Census in West Kilimanjaro. Tanzania, Dry Season, 1997. TWCM Aerial Survey, Unpublished AWF Report.

[25] TAWIRI (2009) Aerial Census in West Kilimanjaro. Tanzania, Dry Season, 2009. TAWIRI Aerial Survey Report.

[26] Kenana, L.M., Bakari, S.K., Bitok, E., Machoke, N.M., Hamza, H.K., Mukeka, J., Chepkwony, R.K. and Mwiu, S.N., (2013) Total Aerial Count for Amboseli-West Kilimanjaro and Magadi-Natron Cross Border Landscape, April 2013. Unpublished Technical Report for KWS, Kenya and TAWIRI, Tanzania.

[27] Norton-Griffiths, M. (1978) Counting Animals. African Wildlife Foundation. 
[28] Dirschl, H., Norton-Griffiths, M. and Wetmore, S.P. (1981) Training Observers for Aerial Surveys of Herbivores. Wildlife Society Bulletin, 9, 108.

[29] Ottichilo, W.K. and Sinange, R.K. (1985) Differences in the Visual and Photographic Measurements in the Estimation of Strip Widths for Aerial Censuses of Animal Populations. DRSRS, Ministry of Planning and National Development, Nairobi.

[30] SPSS (2011) Statistics for Windows, Version 20.0. IBM Corp., Armonk.

[31] KWS \& TAWIRI (2010) Aerial Total Count: Amboseli-West Kilimanjaro and Magadi-Natron Cross Border Landscape, March 2010. Unpublished KWS/TAWIR Report.

[32] Kenana, L.M., Maliti, H.T., Kanga, E.M., Kyale, D.M., Bakari, S.K., Massawe, E.T., Kimutai, D.K, Machoke, N.M., Hamza, H.K. and Mwiu, S.N. (2010) Total Aerial Count for Amboseli-West Kilimanjaro and Magadi-Natron Cross Border Landscape, October 2010. A Technical Report for KWS, Kenya and TAWIRI, Tanzania.

[33] Kenana, L.M., Bakari, S.K., Bitok, E., Machoke, N.M., Hamza, H.K, Mukeka, J., Mwiu, S.N., Kyale, D.M. and Cheptei, J. (2013) Large Mammalaerial Total Count for Amboseli-West Kilimanjaro and Magadi-Natron Cross Border Landscape, October 2013. A Technical Report for Kenya Wildlife Service (KWS), Kenya and Tanzania Wildlife Research Institute (TAWIRI), Tanzania.

[34] Thirgood, S., Mosser, A., Tham, S., Hopcraft, G., Mwangomo, E., Mlengeya, T., Kilewo, M., Fryxell, J., Sinclair, A. R.E. and Borner, M. (2004) Can Parks Protect Migratory Ungulates? The Case of the Serengeti Wildebeest. Animal Conservation, 7, 113-120. http://dx.doi.org/10.1017/S1367943004001404 
Scientific Research Publishing (SCIRP) is one of the largest Open Access journal publishers. It is currently publishing more than 200 open access, online, peer-reviewed journals covering a wide range of academic disciplines. SCIRP serves the worldwide academic communities and contributes to the progress and application of science with its publication.

Other selected journals from SCIRP are listed as below. Submit your manuscript to us via either submit@scirp.org or Online Submission Portal.
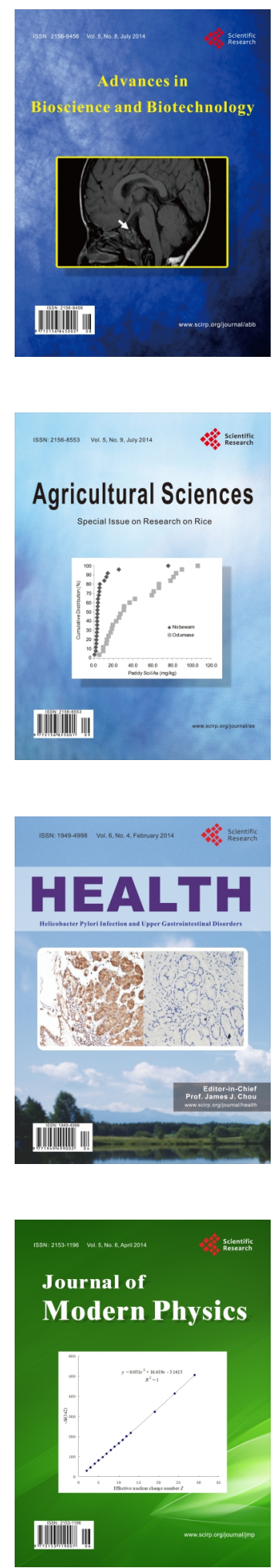
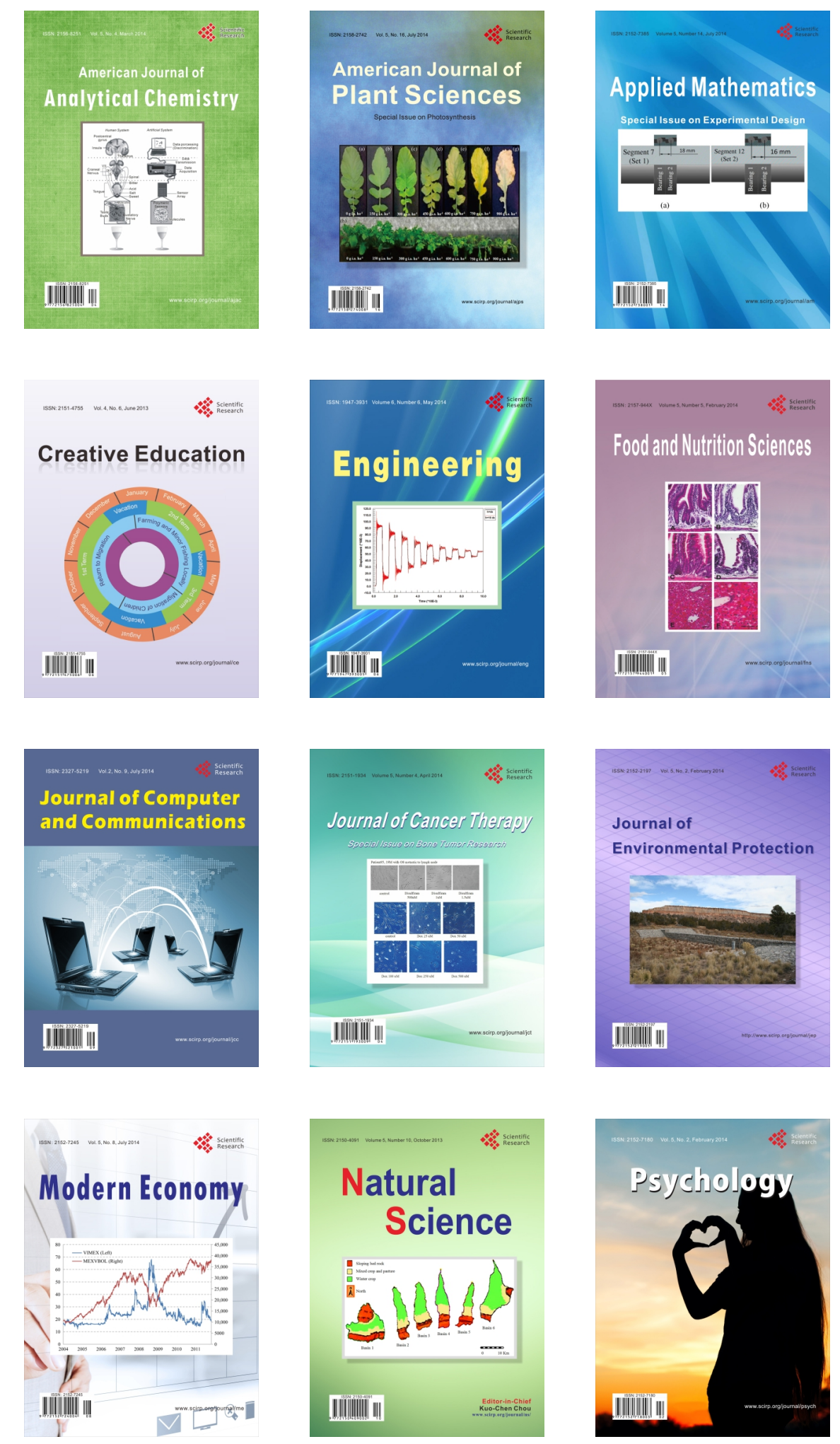